\section{Respiratory acidosis sans acidemia}

\section{Acidémie sans acidose respiratoire}

$\mathrm{T}$ he acid-base changes that result from elevation of the partial pressure of carbon dioxide $\left(\mathrm{PCO}_{2}\right)$ are conventionally analyzed in terms of 'adaptive' increases in plasma bicarbonate concentration $\left(\left[\mathrm{HCO}_{3}^{-}\right]\right)$and the effectiveness of the adaptation is judged by the resulting arterial hydrogen ion concentration $\left(\left[\mathrm{H}^{+}\right]=24 \mathrm{PCO}_{2} /\left[\mathrm{HCO}_{3}{ }^{-}\right]\right)$ (Henderson's equation). From studies dating back 40 years in animals and man $(1,2)$, we learned that acute increases in $\mathrm{pCO}_{2}$ are accompanied by smaller increases in $\left[\mathrm{HCO}_{3}^{-}\right]$(approximately $0.1 \mathrm{mmol} / \mathrm{L}$ for each $\mathrm{mmHg}$ increase in $\mathrm{PCO}_{2}$ ) than when increases in $\mathrm{PCO}_{2}$ are sustained for

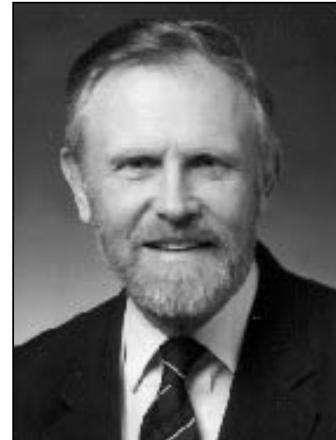

Norman L Jones weeks or longer, as in patients with chronic respiratory failure (approximately $0.35 \mathrm{mmol} / \mathrm{L}$ for each $\mathrm{mmHg}$ increase in $\mathrm{PCO}_{2}$ ). This means that the expected increase in $\left[\mathrm{H}^{+}\right]$(fall in $\mathrm{pH}$ ) resulting from a rapid increase in $\mathrm{PCO}_{2}$ to, say, $60 \mathrm{mmHg}$ is $55 \mathrm{nmol} / \mathrm{L}$ (a pH of 7.25) - greater than in the chronic state, when $\left[\mathrm{H}^{+}\right]$will usually be found around $46 \mathrm{nmol} / \mathrm{L}$ ( $\mathrm{pH} 7.34$ ). Thus, even in the chronic state, $\left[\mathrm{H}^{+}\right]$is still expected to be elevated, leading us to conclude that the 'adaptation' is never perfect. When normal arterial $\left[\mathrm{H}^{+}\right]$is encountered in chronic respiratory failure, the finding is usually explained by a complicating metabolic alkalosis secondary to diuretic or steroid therapy, or perhaps to transient hyperventilation at the time of arterial blood sampling.

As described in their paper on pages 311 to 315 of the present issue of the Canadian Respiratory Journal, Tereza Martinu, Dick Menzies and Sandra Dial had the impression that in many of their patients with a stable elevation of arterial $\mathrm{PCO}_{2}$, such factors could not explain a $\mathrm{pH}$ within the normal range. They set out to re-examine the relationships between a chronically elevated arterial $\mathrm{PCO}_{2}$ and the associated increases in arterial plasma $\left[\mathrm{HCO}_{3}^{-}\right]$and $\left[\mathrm{H}^{+}\right]$by reviewing the records of patients known to have chronic hypercapnia but who were not on steroids or diuretics. Eighteen patients met the criteria for clinical stability and therapy, and the impressively close relationship between $\mathrm{PCO}_{2}$ and $\left[\mathrm{HCO}^{-}\right]$shown in Figure 4 of their paper indeed showed that $\left[\mathrm{HCO}_{3}^{-}\right]$increased to a greater extent than the conventional rule of thumb - by $0.51 \mathrm{mmol} / \mathrm{L}$ for every $\mathrm{mmHg}$ increase in $\mathrm{PCO}_{2}$. Using the above example of a rise in $\mathrm{PCO}_{2}$ to $60 \mathrm{mmHg}$, we should expect $\left[\mathrm{HCO}_{3}^{-}\right]$to be $34.2 \mathrm{mmol} / \mathrm{L}$ and $\left[\mathrm{H}^{+}\right]$to be $42 \mathrm{nmol} / \mathrm{L}(\mathrm{pH} 7.38$ ) in such patients.

Table 4 of Martinu et al's paper, perhaps surprisingly, shows that three of the four quoted previous studies of chronic respiratory failure found comparable results. The difference between their findings and the conventional rule of thumb may appear small in terms of $\mathrm{pH}$ - a difference between 7.38 and 7.34 at a $\mathrm{PCO}_{2}$ of $60 \mathrm{mmHg}$ - and the response is within the wide expected range of 7.28 to $7.40(3,4)$. However, their observation should lead to a reappraisal of the rule of thumb mentation de $\mathrm{mmHg}$ de $\mathrm{PCO}_{2}$ ) que lorsque les augmentations de $\mathrm{PCO}_{2}$ durent plusieurs semaines, comme chez les patients souffrant d'insuffisance respiratoire chronique (environ 0,35 mmol/L pour chaque augmentation de $\mathrm{mmHg}$ de $\mathrm{PCO}_{2}$ ). Ainsi, l'augmentation prévue de $\left[\mathrm{H}^{+}\right]$(baisse de $\mathrm{pH}$ ) causée par une augmentation rapide de $\mathrm{PCO} 2$ jusqu'à, par exemple, $60 \mathrm{mmHg}$ est $55 \mathrm{nmol} / \mathrm{L}$ (un pH de 7,25), soit plus élevée que lorsqu'il s'agit d'une maladie chronique alors que le $\left[\mathrm{H}^{+}\right]$ s'élèvera habituellement autour de 46 nmol/L ( $\mathrm{pH} 7,34$ ). Donc, même pour les cas chroniques, le $\left[\mathrm{H}^{+}\right]$sera encore élevé nous portant à croire que l'adaptation n'est jamais parfaite. Un $\left[\mathrm{H}^{+}\right]$ artériel normal dans le cas d'une insuffisance respiratoire chronique s'explique habituellement par une alcalose métabolique suite à une thérapie aux diurétiques ou aux stéroïdes ou parfois à une hyperventilation transitoire au moment de la prise d'échantillon de sang artériel.

Tel que décrit dans leur article aux pages 311 à 315 du présent numéro du Canadian Respiratory Journal, Tereza Martinu, Dick Menzies et Sandra Dial avaient l'impression que dans le cas de plusieurs de leurs patients ayant une augmentation stable de $\mathrm{PCO}_{2}$ artériel, ces facteurs n'expliquaient pas un $\mathrm{pH}$ normal. Ils ont tenté de réexaminer les liens entre un $\mathrm{PCO}_{2}$ artériel élevé de façon chronique et les augmentations liées de $\left[\mathrm{HCO}_{3}^{-}\right]$et de $\left[\mathrm{H}^{+}\right]$dans le sang artériel en étudiant les dossiers de patients qui souffraient d'hypercapnie mais ne subissaient pas de traitement aux stéroïdes ou aux diurétiques. Dix-huit patients correspondaient aux critères de stabilité clinique et de thérapie, et le lien extrêmement étroit entre le $\mathrm{PCO}_{2}$ et le $\left[\mathrm{HCO}_{3}^{-}\right]$présenté à la Figure 4 de leur article démontre en effet que le $\left[\mathrm{HCO}_{3}{ }^{-}\right]$a augmenté davantage que la règle conventionnelle, soit de $0,51 \mathrm{mmol} / \mathrm{L}$ pour chaque augmentation de $\mathrm{mmHg}$ de $\mathrm{PCO}_{2}$. À l'aide de l'exemple précédent d'une hausse de $\mathrm{PCO}_{2}$ à $60 \mathrm{mmHg}$, nous devrions nous attendre à un $\left[\mathrm{HCO}_{3}{ }^{-}\right]$de $34,2 \mathrm{mmol} / \mathrm{L}$ et un $\left[\mathrm{H}^{+}\right]$de $42 \mathrm{nmol} / \mathrm{L}(\mathrm{pH} 7,38)$ pour ces patients.

Le Tableau 4 de l'article de Martinu et al montre peut-être de façon surprenante que trois des quatre études mentionnées sur l'insuffisance respiratoire chronique affichaient des résultats comparables. La différence entre leurs résultats et la règle conventionnelle peut paraître mince en termes de $\mathrm{pH}$, soit une 
usually applied in the interpretation of clinical acid-base relationships. The explanation for their findings in mechanistic terms and for the unexpected 'perfect' adaptive response should encourage observations that use more modern concepts than those used 30 to 40 years ago when most of these relationships were established.

Twenty years ago, Peter Stewart stirred up a hornet's nest of controversy, especially among renal physiologists, with a paper published in the Canadian Journal of Physiology and Pharmacology entitled "Modern quantitative acid-base chemistry" (5). However, his approach was enthusiastically adopted by many respiratory and exercise physiologists, as evidenced by accompanying commentaries by Don Jennings and Robert Blake Reeves (6). Stewart proposed that with the advent of computers, the complex interactions between all of the ionic species influencing acid-base homeostasis could be quantified using classical thermodynamic and physicochemical logic, in which the balance between ionic concentrations is governed by the laws of mass action, electrical neutrality and conservation of mass. More importantly, he argued that it was essential to identify which variables could be classed as independent, and thus 'controlling', and which had to be classed as dependent, and thus 'controlled'. Independent variables were $\mathrm{PCO}_{2}$, net strong ion charge ([SID]) and total weak acid ('buffer') concentration $\left(\left[\mathrm{A}_{\text {tot }}\right]\right)$. Dependent variables include $\left[\mathrm{H}^{+}\right]$, $\left[\mathrm{HCO}_{3}{ }^{-}\right]$and the dissociated weak (buffer) anions ([A-]). It follows from this logic that dependent variables such as $\left[\mathrm{H}^{+}\right]$and $\left[\mathrm{HCO}_{3}{ }^{-}\right]$do not depend on the total amount that is potentially available - consisting of $[\mathrm{H}+]$ in water and $\left[\mathrm{HCO}_{3}^{-}\right]$in body carbonate and $\mathrm{HCO}_{3}{ }^{-}$stores. In plasma, the independent variables, for practical purposes, can be measured by $\mathrm{PCO}_{2}$, [SID] [sodium $\left(\mathrm{Na}^{+}\right)+$potassium $\left(\mathrm{K}^{+}\right)$- chloride $\left(\mathrm{Cl}^{-}\right)$- lactate-] and $\left[\mathrm{A}_{\text {tot }}\right]$ (total plasma protein content in $\mathrm{g} / \mathrm{L} \times 0.24$ ), allowing their separate contributions to changes in $\left[\mathrm{H}^{+}\right]$and $\left[\mathrm{HCO}_{3}{ }^{-}\right]$to be calculated. It may be hard to see why the approach has been so controversial, but in part it may be due to some of the physiological implications that went against conventional thinking. Among these may be that we cannot view $\left[\mathrm{H}^{+}\right]$as being controlled solely by the ratio of $\mathrm{PCO}_{2}$ to $\left[\mathrm{HCO}_{3}{ }^{-}\right]$as expressed in Henderson's equation; that renal $\mathrm{HCO}_{3}{ }^{-}$reabsorption per se can play no direct part in acid-base control; and that the administration of $\mathrm{HCO}_{3}{ }^{-}$solutions to patients can have no direct effect (other than providing $\mathrm{Na}^{+}$or raising $\mathrm{PCO}_{2}$ if they are not breathing). Stewart's approach is equally applicable to intracellular conditions (7) (indeed to any aqueous solution) and will continue to provide insights into acid-base homeostasis.

How then may we apply Stewart's approach to what is happening in chronic respiratory failure? Conceptually, we must concentrate on the independent variables; the dependent variables, $\left[\mathrm{H}^{+}\right]$and $\left[\mathrm{HCO}_{3}^{-}\right]$, do not drive the process but are simply the result of the chemical equilibrium determined by the independent variables. We must look to 'adaptive' changes in $[\mathrm{SID}]$ and $\left[\mathrm{A}_{\mathrm{tot}}\right]$ that minimize potential increases in $\left[\mathrm{H}^{+}\right]$ caused by elevations in $\mathrm{PCO}_{2}$. [SID] increases because of reductions in $\left[\mathrm{Cl}^{-}\right]$due to its renal excretion and to its movement into erythrocytes and other tissues; increases in $\left[\mathrm{Na}^{+}\right]$ and/or $\left[\mathrm{K}^{+}\right]$are much less likely. Plasma protein concentration $\left(\left[\mathrm{A}_{\text {tot }}\right]\right)$ may fall due to fluid retention ('dilutional alkalosis') différence entre 7,38 et 7,34 pour un $\mathrm{PCO}_{2}$ de $60 \mathrm{mmHg}$, et la réaction est dans la gamme prévue de 7,28 à 7,40 (3,4). Leur observation devrait toutefois mener à une réévaluation de la règle appliquée à l'interprétation des liens acide-base cliniques. L'explication de leurs résultats en termes mécanistes et pour la réaction adaptée parfaite inattendue devrait susciter des observations fondées sur des concepts plus modernes que ceux utilisés il y a 30 à 40 ans quand la plupart de ces liens ont été établis.

Il y a vingt ans, Peter Stewart a semé une vive controverse, surtout auprès des physiologistes rénaux, avec la publication d'un article dans la Revue canadienne de physiologie et de pharmacologie intitulé « Modern quantitative acid-base chemistry » (5). Son approche a cependant été adoptée avec enthousiasme par plusieurs spécialistes des troubles respiratoires et de l'exercice, comme en témoignent les commentaires de Don Jennings et Robert Blake Reeves (6). Selon Stewart, avec l'avènement des ordinateurs, les interactions complexes entre les divers ions qui influent sur l'homéostasie acide-base pourraient être quantifiés à l'aide de la logique thermodynamique et physico-chimique, selon laquelle l'équilibre entre les concentrations ioniques est régi par les lois de l'action de masse, la neutralité électrique et la conservation de la masse. Il avance de plus qu'il était essentiel d'identifier les variables qui peuvent être classées comme indépendantes, et donc contrôlantes, et celles qui peuvent être classées comme dépendantes, et donc contrôlées. Les variables indépendantes étaient le $\mathrm{PCO}_{2}$, la charge ionique forte nette ([SID]) et la concentration totale d'acide faible (tampon) $\left(\left[\mathrm{A}_{\text {tot }}\right]\right)$. Les variables dépendantes comprennent le $[\mathrm{H}+]$, le $\left[\mathrm{HCO}_{3}^{-}\right]$et les anions faibles dissociés (tampon) ([ $\left.\mathrm{A}^{-}\right]$). Selon cette logique, les variables dépendantes telles le $[\mathrm{H}+]$ et le $\left[\mathrm{HCO}_{3}^{-}\right]$ne dépendent pas de la quantité totale disponible, qui consiste en $\left[\mathrm{H}^{+}\right]$dans l'eau et de $\left[\mathrm{HCO}_{3}^{-}\right]$dans le carbonate du corps et les réserves de $\mathrm{HCO}_{3}^{-}$. Dans le plasma, les variables indépendantes, à des fins pratiques, se mesurent en $\mathrm{PCO}_{2}$, [SID] [sodium $\left(\mathrm{Na}^{+}\right)+$potassium $\left(\mathrm{K}^{+}\right)$- chlorure $\left(\mathrm{Cl}^{-}\right)$- lactate $]$et $\left[\mathrm{A}_{\text {tot }}\right]$ (contenu protéinique total du plasma en $\mathrm{g} / \mathrm{L} \times 0.24)$, permettant de calculer leur apport individuel dans les changements de $\left[\mathrm{H}^{+}\right]$de $\left[\mathrm{HCO}_{3}{ }^{-}\right]$. Il peut être difficile de voir pourquoi cette approche était si controversée, mais ceci peut s'expliquer en partie par les conséquences physiologiques qui allaient à l'encontre de la pensée conventionnelle. Entre autres, nous ne pouvons pas concevoir que le $\left[\mathrm{H}^{+}\right]$est uniquement contrôlé par le rapport entre $\mathrm{PCO}_{2}$ et $\left[\mathrm{HCO}_{3}{ }^{-}\right]$tel qu'exprimé dans l'équation de Henderson; que la réabsorption rénale de $\mathrm{HCO}_{3}{ }^{-}$comme tel ne joue aucun rôle dans le contrôle acide-base; et que l'administration de solutions de $\mathrm{HCO}_{3}{ }^{-}$aux patients ne peut avoir d'effet direct (autre que de fournir du $\mathrm{Na}+$ ou d'augmenter le $\mathrm{PCO}_{2}$ s'ils ne respirent pas). L'approche de Stewart est tout autant applicable aux conditions intracellulaires (7) (en fait à toute solution aqueuse) et continue d'approfondir les connaissances sur l'homéostasie acide-base.

Comment pouvons-nous appliquer l'approche de Stewart à l'insuffisance respiratoire chronique? En principe, nous devons nous concentrer sur les variables indépendantes; les variables dépendantes, le $\left[\mathrm{H}^{+}\right]$et le $\left[\mathrm{HCO}_{3}{ }^{-}\right]$ne déclenchent pas le processus : elles ne sont que le résultat de l'équilibre chimique provoqué par les variables indépendantes. Nous devons rechercher des changements adaptés de $[\mathrm{SID}]$ et de $\left[\mathrm{A}_{\text {tot }}\right]$ qui réduisent les augmentations possibles de $\left[\mathrm{H}^{+}\right]$causées par une 
or perhaps to malnutrition. To explain why $\left[\mathrm{HCO}_{3}^{-}\right]$is $34 \mathrm{mmol} / \mathrm{L}$ at a $\mathrm{PCO}_{2}$ of $60 \mathrm{mmHg}$, as found by Martinu et al, rather than $31 \mathrm{mmol} / \mathrm{L}$ (conventional rule-of-thumb), $\left[\mathrm{Cl}^{-}\right]$ needs to be only $3 \mathrm{mmol} / \mathrm{L}$ lower or the plasma protein concentration needs to be only 10 to $15 \mathrm{~g} / \mathrm{L}$ lower. The likelihood of such explanations, either singly or in combination, seems considerable. However, in the most complete study so far of patients with chronic hypercapnia (8) - incredibly containing patients with $\mathrm{PCO}_{2} \mathrm{~s}$ as high as $105 \mathrm{mmHg}$ and $\left[\mathrm{HCO}_{3}{ }^{-}\right]$of $55 \mathrm{mmol} / \mathrm{L}-\left[\mathrm{Cl}^{-}\right]$did not fall below $82 \mathrm{mmol} / \mathrm{L}$, associated with $\left[\mathrm{Na}^{+}\right]$no higher than $145 \mathrm{mmol} / \mathrm{L}$. This suggests that the rise in $\left[\mathrm{HCO}_{3}^{-}\right]$cannot be totally accounted for by hypochloremia and the associated increase in [SID]. Within the schema of Stewart (5), we need other explanations that may widen $[\mathrm{SID}]$ or reduce $\left[\mathrm{A}_{\text {tot }}\right]$. Increases in $\mathrm{PCO}_{2}$ have profound effects on metabolic biochemistry, cerebral blood flow, cell membrane receptors and ion channels, and hormone secretion; changes in some or all of these functions could conceivably be acting to produce such changes. Although most of these effects are well known, their relative importance in the integrated responses to chronic hypercapnia remains poorly understood, in spite of the wealth of research undertaken during the past half-century. Whatever the eventual outcome, there seems little doubt that the simplistic control of plasma $\mathrm{pH}$, through a feedback loop involving changes in $\left[\mathrm{HCO}_{3}{ }^{-}\right]$, will end up in the waste basket.

\section{Norman L Jones MD}

Founding Editor-in-Chief, Canadian Respiratory Journal McMaster University, Hamilton, Ontario

jonesn@mcmaster.ca

\section{REFERENCES}

1. Polak A, Haynie GD, Hays M, Schwartz WB. Effects of chronic hypercapnia on electrolyte and acid-base equilibrium. J Clin Invest 1961;40:1223-37.

2. Schwartz WB, Cohen JJ, Brackett NC Jr. The response of extracellular hydrogen ion concentration to graded degrees of chronic hypercapnia: The physiologic limits of the defense of $\mathrm{pH}$. J Clin Invest 1965;44:291-301.

3. Gibson GJ. Respiratory function tests. Chapter 5. In: Brewis RAL, Corrin B, Geddes DM, Gibson GJ, eds. Respiratory Medicine, 2nd edn. London: WB Saunders Co, 1995:264-77.

4. Elliott CG, Morris AH. Clinical syndromes of respiratory acidosis and alkalosis. Chapter 19. In: Seldin DW, Giebisch G. The regulation of acids-base balance. New York: Raven Press, 1989:483-521.

5. Stewart PA. Modern quantitative acid-base chemistry. Can J Physiol Pharmacol 1983;61:1444-61.

6. Jennings DB, Reeves RB. Modern quantitative acid-base chemistry. Can J Physiol Pharmacol 1983;61:1442-3.

7. Jones NL. Acid-base physiology. In: Crystal RG, West JB, eds. The Lung: Scientific Foundations. New York: Raven Press, 1991:1251-65.

8. Engel K, Dell RB, Rahill WJ, Denning CR, Winters RW. Quantitative displacement of acid-base equilibrium in chronic respiratory acidosis. J Appl Physiol 1968;24:288-95. élévation de $\mathrm{PCO}_{2}$. Le [SID] augmente à cause d'une réduction de $\left[\mathrm{Cl}^{-}\right]$en raison de son excrétion rénale et à son mouvement dans les érythrocytes et autres tissus; les augmentations de $\left[\mathrm{Na}^{+}\right]$et de $\left[\mathrm{K}^{+}\right]$sont beaucoup moins probables. La concentration protéinique du plasma $\left(\left[\mathrm{A}_{\mathrm{tot}}\right]\right)$ peut baisser à cause d'une rétention de fluides (alcalose dilutionnelle) ou peut-être de malnutrition. Pour expliquer pourquoi le $\left[\mathrm{HCO}_{3}{ }^{-}\right]$ est $34 \mathrm{mmol} / \mathrm{L}$ à une $\mathrm{PCO}_{2}$ de $60 \mathrm{mmHg}$, tel qu'indiqué par Martinu et al, plutôt que $31 \mathrm{mmol} / \mathrm{L}$ (règle conventionnelle), $\left[\mathrm{Cl}^{-}\right]$doit être seulement $3 \mathrm{mmol} / \mathrm{L}$ moins élevé ou la concentration protéinique du plasma doit être seulement de 10 à $15 \mathrm{~g} / \mathrm{L}$ moins élevée. La possibilité de ces explications, soit individuellement ou en combinaison, semble vraisemblable. Dans l'étude la plus complète à ce jour de patients avec une hypercapnie chronique (8), qui comporte des patients ayant une $\mathrm{PCO}_{2}$ aussi élevée que $105 \mathrm{mmHg}$ et un $\left[\mathrm{HCO}_{3}{ }^{-}\right]$de $55 \mathrm{mmol} / \mathrm{L}$, le $\left[\mathrm{Cl}^{-}\right]$n'est pas descendu sous les $82 \mathrm{mmol} / \mathrm{L}$, avec un $\left[\mathrm{Na}^{+}\right]$d'au plus $145 \mathrm{mmol} / \mathrm{L}$. Ceci suggère que la hausse de $\left[\mathrm{HCO}_{3}^{-}\right]$n'est pas entièrement attribuable à l'hypochlorémie et la hausse liée de [SID]. Dans le schéma de Stewart (5), d'autres explications s'imposent pour élargir le [SID] ou réduire le $\left[\mathrm{A}_{\text {tot }}\right]$. Les hausses de la $\mathrm{PCO}_{2}$ ont d'importantes répercussions sur la biochimie métabolique, le flux sanguin cérébral, les récepteurs de membranes cellulaires et les canaux ioniques et la sécrétion d'hormones; des modifications affectant l'une ou l'autre de ces fonctions pourraient éventuellement agir pour produire ce type de changements. Bien que la plupart de ces effets soient bien connus, leur importance relative dans les réactions intégrées à l'hypercapnie chronique demeure mal connue, malgré une multitude d'études entreprises au cours des cinquante dernières années. Peu importe les résultats futurs, il semble probable que le contrôle simpliste du $\mathrm{pH}$ sanguin, par une boucle de rétroaction mettant en cause des changements de $\left[\mathrm{HCO}_{3}^{-}\right]$, sera mis de côté.

\section{Norman L Jones $\mathrm{MD}$ Éditeur en chef fondateur, Canadian Respiratory Journal Université McMaster, Hamilton, Ontario jonesn@mcmaster.ca}

\section{RÉFÉRENCES}

1. Polak A, Haynie GD, Hays M, Schwartz WB. Effects of chronic hypercapnia on electrolyte and acid-base equilibrium. J Clin Invest 1961;40:1223-37.

2. Schwartz WB, Cohen JJ, Brackett NC Jr. The response of extracellular hydrogen ion concentration to graded degrees of chronic hypercapnia: The physiologic limits of the defense of $\mathrm{pH}$. J Clin Invest 1965;44:291-301.

3. Gibson GJ. Respiratory function tests. Chapter 5. In: Brewis RAL, Corrin B, Geddes DM, Gibson GJ, eds. Respiratory Medicine, 2nd edn. London: WB Saunders Co, 1995:264-77.

4. Elliott CG, Morris AH. Clinical syndromes of respiratory acidosis and alkalosis. Chapter 19. In: Seldin DW, Giebisch G. The regulation of acids-base balance. New York: Raven Press, 1989:483-521.

5. Stewart PA. Modern quantitative acid-base chemistry. Can J Physiol Pharmacol 1983;61:1444-61.

6. Jennings DB, Reeves RB. Modern quantitative acid-base chemistry. Can J Physiol Pharmacol 1983;61:1442-3.

7. Jones NL. Acid-base physiology. In: Crystal RG, West JB, eds. The Lung Scientific Foundations. New York: Raven Press, 1991:1251-65.

8. Engel K, Dell RB, Rahill WJ, Denning CR, Winters RW. Quantitative displacement of acid-base equilibrium in chronic respiratory acidosis. J Appl Physiol 1968;24:288-95. 


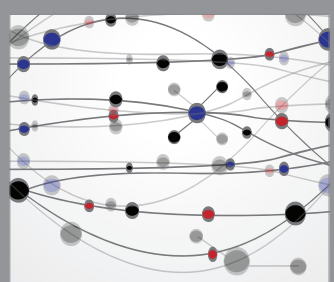

The Scientific World Journal
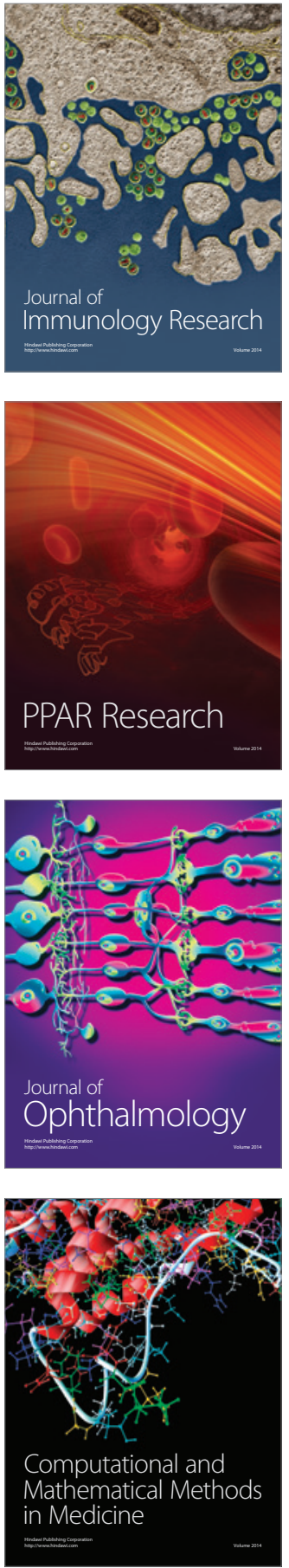

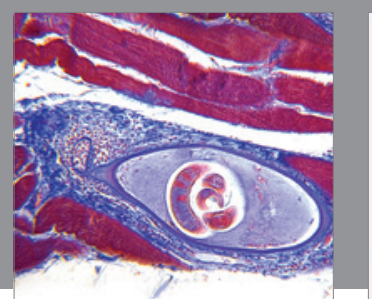

Gastroenterology Research and Practice

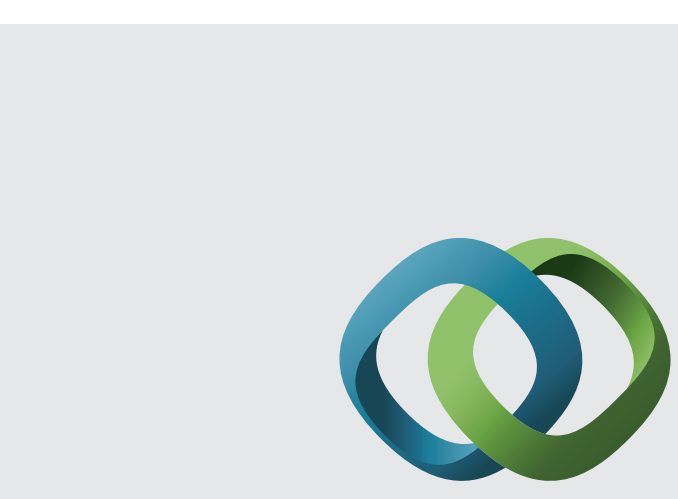

\section{Hindawi}

Submit your manuscripts at

http://www.hindawi.com
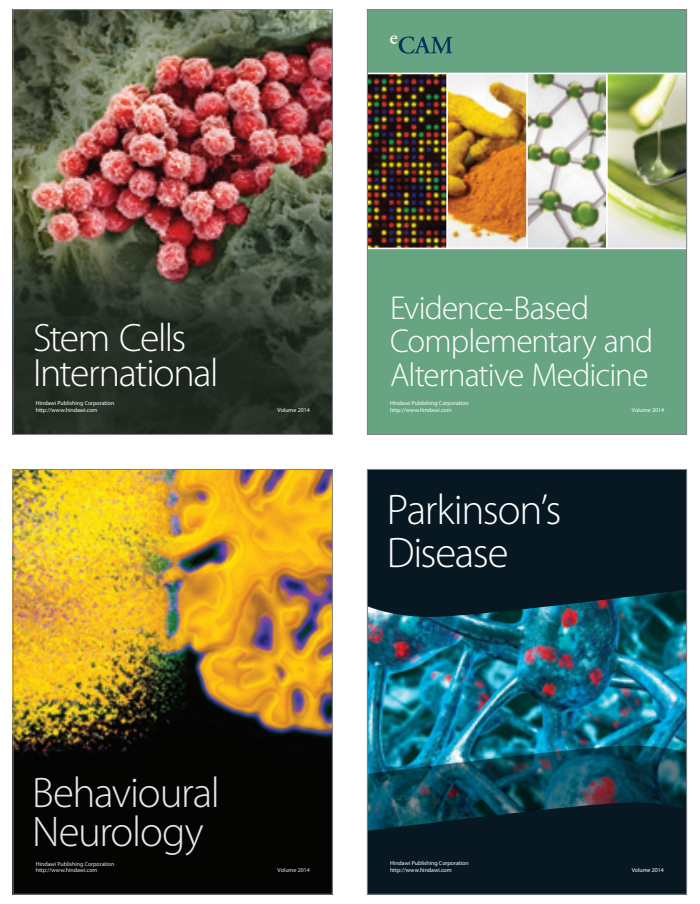
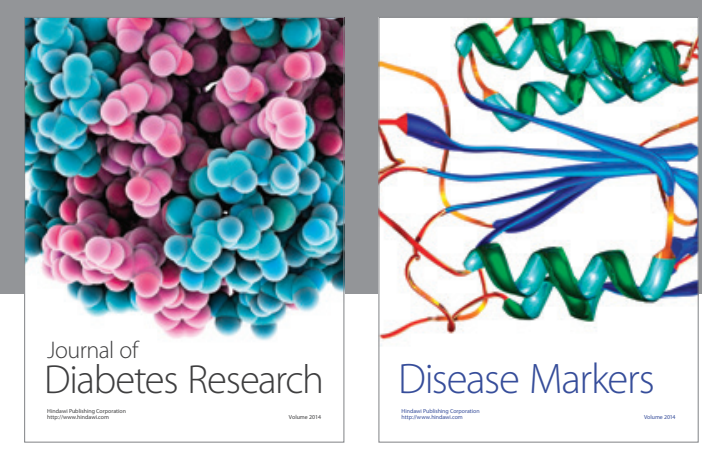

Disease Markers
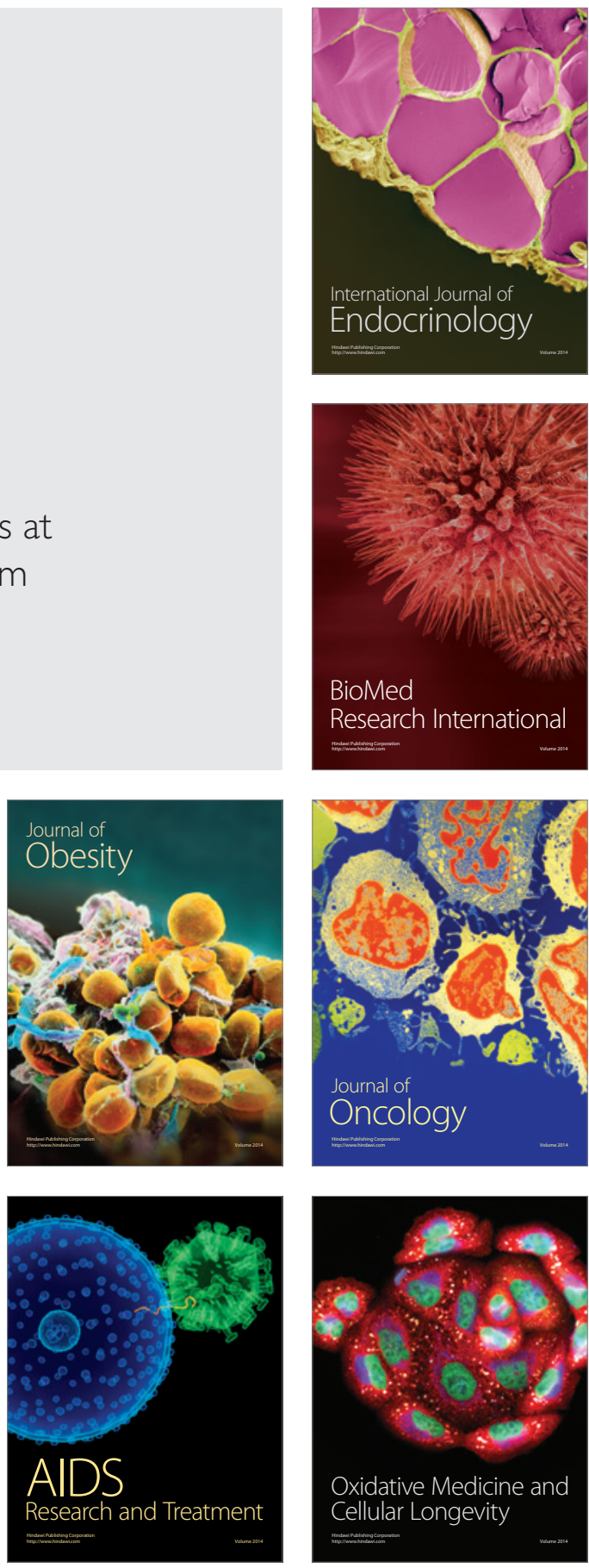